\title{
A New Map of Standardized Terrestrial Ecosystems of the Conterminous United States
}

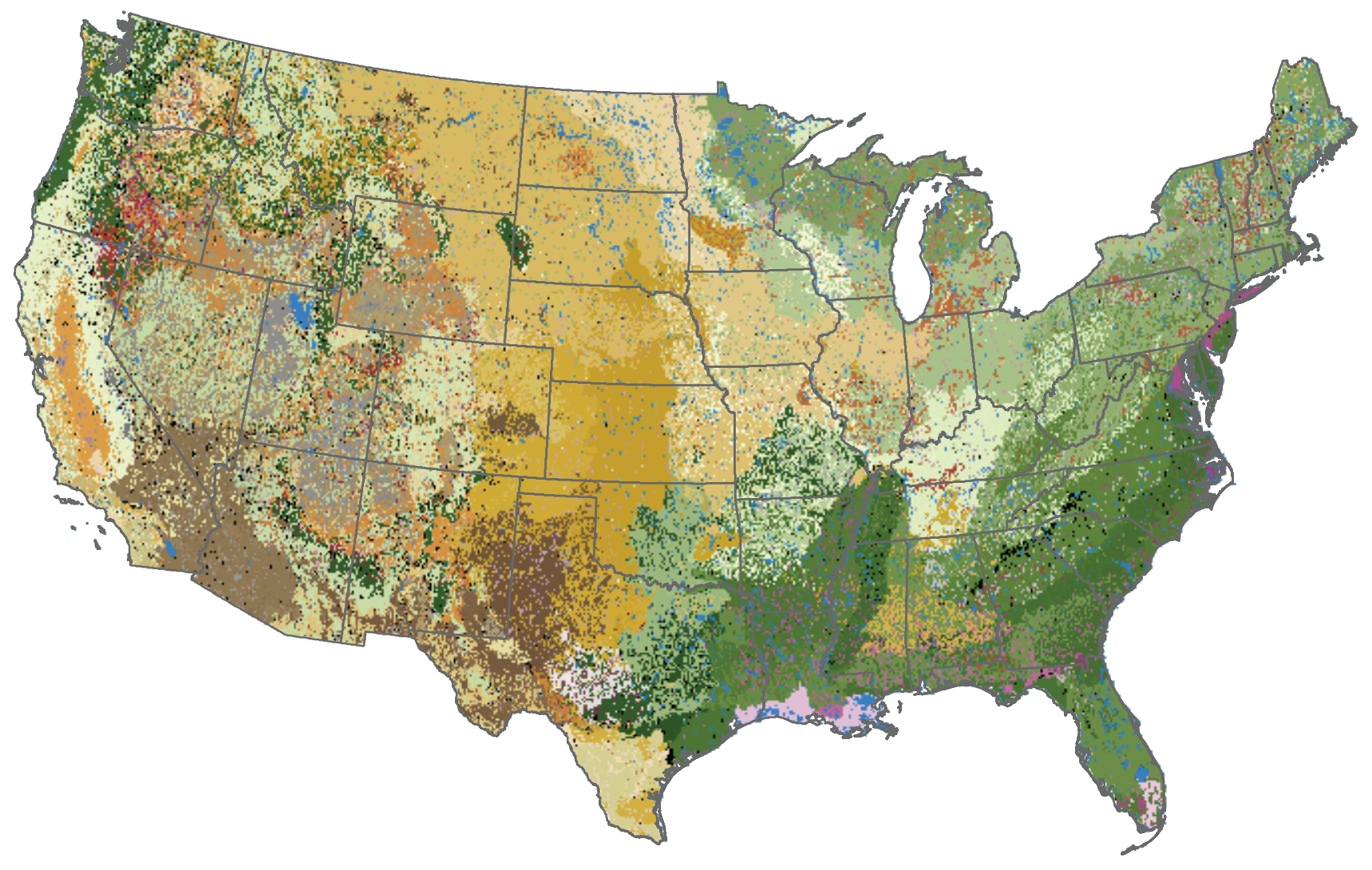

Professional Paper 1768 
Front cover: Map of the conterminous United States showing terrestrial ecosystems that were deductively modeled through biophysical stratification of the area into ecosystem footprints (physically distinct areas) and subsequent attribution of these footprints with a NatureServe ecosystem type. See figure 8 in the text. 


\section{A New Map of Standardized Terrestrial Ecosystems of the Conterminous United States}

By Roger Sayre, Patrick Comer, Harumi Warner, and Jill Cress

Professional Paper 1768 


\title{
U.S. Department of the Interior \\ KEN SALAZAR, Secretary
}

\author{
U.S. Geological Survey \\ Suzette M. Kimball, Acting Director
}

U.S. Geological Survey, Reston, Virginia: 2009

For more information on the USGS - the Federal source for science about the Earth, its natural and living resources, natural hazards, and the environment, visit http://www.usgs.gov or call 1-888-ASK-USGS

For an overview of USGS information products, including maps, imagery, and publications, visit http://www.usgs.gov/pubprod

To order this and other USGS information products, visit http://store.usgs.gov

For more information about global ecosystem studies by the U.S. Geological Survey and its partners, visit http://rmgsc.cr.usgs.gov/ecosystems

Any use of trade, product, or firm names is for descriptive purposes only and does not imply endorsement by the U.S. Government.

Although this report is in the public domain, permission must be secured from the individual copyright owners to reproduce any copyrighted materials contained within this report.

Suggested citation:

Sayre, Roger, Comer, Patrick, Warner, Harumi, and Cress, Jill, 2009, A new map of standardized terrestrial ecosystems of the conterminous United States: U.S. Geological Survey Professional Paper 1768, 17 p. (Also available online.) 


\section{Contents}

Abstract
Introduction.
Deductive and Inductive Approaches to Ecosystem Modeling
Methodology
Acknowledgments
References Cited.

\section{Figures}

1. Diagram of the vertical structure of an ecosystem, showing the spatial integration of biological and nonliving components...

2. Schematic depiction of the geospatial modeling approach to terrestrial ecosystems mapping .

3-8. Maps of the conterminous United States showing-

3. NatureServe's ecological divisions

4. Mesoscale isobioclimate regions, representing areas of distinct ombrotype (wet/dry gradients) and thermotype (hot/cold gradients) regimes.........6

5. Lithology of surficial materials, depicting the distributions of 17 distinct substrate types

6. Landform classes modeled using 30-m digital elevation data and derived from neighborhood analyses of slope and relative relief.

7. Topographic moisture potential index modeled using 30-m digital elevation data and derived from analyses of potential accumulation of moisture at a point based on topography.

8. Terrestrial ecosystems that were deductively modeled through biophysical stratification of the area into ecosystem footprints (physically distinct areas) and subsequent attribution of these footprints with a NatureServe ecosystem type

9. Map showing terrestrial ecosystems in a $6,000-\mathrm{km}^{2}$ section of northeastern Utah........12

\section{Table}

1. Land surface form classes topographically modeled from combinations of slope class and local relief 


\section{Conversion Factors}

\begin{tabular}{|c|c|c|}
\hline Multiply & By & To obtain \\
\hline \multicolumn{3}{|c|}{ Length } \\
\hline meter $(\mathrm{m})$ & 3.281 & foot $(\mathrm{ft})$ \\
\hline \multicolumn{3}{|c|}{ Area } \\
\hline hectare (ha) & 2.471 & acre \\
\hline square kilometer $\left(\mathrm{km}^{2}\right)$ & 0.3861 & square mile $\left(\mathrm{mi}^{2}\right)$ \\
\hline
\end{tabular}




\title{
A New Map of Standardized Terrestrial Ecosystems of the Conterminous United States
}

\author{
By Roger Sayre, ${ }^{1}$ Patrick Comer, ${ }^{2}$ Harumi Warner, ${ }^{3}$ and Jill Cress ${ }^{4}$
}

\section{Abstract}

A new map of standardized, mesoscale (tens to thousands of hectares) terrestrial ecosystems for the conterminous United States was developed by using a biophysical stratification approach. The ecosystems delineated in this top-down, deductive modeling effort are described in NatureServe's classification of terrestrial ecological systems of the United States. The ecosystems were mapped as physically distinct areas and were associated with known distributions of vegetation assemblages by using a standardized methodology first developed for South America. This approach follows the geoecosystems concept of R.J. Huggett and the ecosystem geography approach of R.G. Bailey.

Unique physical environments were delineated through a geospatial combination of national data layers for biogeography, bioclimate, surficial materials lithology, land surface forms, and topographic moisture potential. Combining these layers resulted in a comprehensive biophysical stratification of the conterminous United States, which produced 13,482 unique biophysical areas. These were considered as fundamental units of ecosystem structure and were aggregated into 419 potential terrestrial ecosystems.

The ecosystems classification effort preceded the mapping effort and involved the independent development of diagnostic criteria, descriptions, and nomenclature for describing expert-derived ecological systems. The aggregation and labeling of the mapped ecosystem structure units into the ecological systems classification was accomplished in an iterative, expert-knowledge-based process using automated rulesets for identifying ecosystems on the basis of their biophysical and biogeographic attributes. The mapped ecosystems, at a 30-meter base resolution, represent an improvement in spatial and thematic (class) resolution over existing ecoregionalizations and are useful for a variety of applications, including ecosystem services assessments, climate change impact studies, biodiversity conservation, and resource management.

\footnotetext{
${ }^{1}$ U.S. Geological Survey, Reston, VA.

${ }^{2}$ Ecology Department, NatureServe, Boulder, CO.

${ }^{3}$ Parallel Inc., Lakewood, CO.

${ }^{4}$ U.S. Geological Survey, Denver, CO.
}

\section{Introduction}

Ecosystems provide many benefits to human societies as goods (such as food, fuel, and fiber) and services (such as water purification, maintenance of soil fertility, and pollination). Sustained provision of these goods and services is important for human societies, but recent studies like that by the Millennium Ecosystem Assessment (2005) have shown that degraded ecosystems are compromised in their ability to provide these benefits. In order for existing ecosystems to persist on the planet, they will need to be well managed. Many U.S. agencies and international organizations now promote ecosystem-based management approaches; these groups include the U.S. Bureau of Land Management (1994), the U.S. Department of Agriculture (USDA) Forest Service (2006a, p. 22), the U.S. Geological Survey (as described by Myers and others (2007)), the United Nations Environment Programme (which supports the Secretariat of the Convention on Biological Diversity, 2000), and the Group on Earth Observations (2005). Management of ecosystems necessarily requires an understanding of the types, spatial pattern and scales, and distributions of ecosystems that occur within the management jurisdiction.

Ecosystem definition, classification, and mapping have received considerable attention since ecosystems were first championed by Tansley (1935). Odum (1953), in his seminal textbook on ecology, recognized ecosystems as systems of biotic communities interacting with their physical environment. These early definitional concepts have evolved into different lines of investigation into ecosystem structure, ecosystem function, ecosystem condition, ecosystem geography, and, most recently, ecosystem services. The study of ecosystem pattern and process in their regional contexts has become the principal focus of landscape ecologists (Wu and Hobbs, 2007), and ecosystem geographers analyze and map the spatial distribution of ecosystems at multiple scales (Bailey, 1996).

The trend towards ecologically oriented management has been associated with the development of a number of different classifications and maps of ecosystems at scales ranging from global to local. In the United States, an Interagency Ecosystem Management Task Force (1995) concluded that ecosystem delineation is necessary to establish a geospatial 
framework for resource management. Global and regional ecosystems have been defined in many macroscale (thousands to tens of thousands of hectares) ecoregionalizations of the planet (Bailey, 1998a; Olson and others, 2001) and the United States (Omernik, 1987; Bailey, 1996; Commission for Environmental Cooperation, 1997; Ricketts and others, 1999; Groves and others, 2000). In the United States, different Federal land management agencies use different macroscale ecoregional classification systems (for examples, see Omernik, 1987; Cleland, Avers, and others, 1997; Cleland, Freeouf, and others, 2005). In 1996, nine Federal agencies agreed to develop a spatial framework of common ecological regions as areas within which biotic and abiotic capacities and potentials are similar (McMahon and others, 2001). This framework is still in development in 2009. Today, standardized maps of ecosystems are increasingly available for regions of the United States (for example, Lowry and others, 2005; Ryan and others, 2006), but standardized, nationally comprehensive ecosystem maps delineated at management-appropriate scales (tens to thousands of hectares) are not yet available. The lack of such information resulted in this effort to produce a new map of terrestrial ecosystems for the conterminous United States.

Building on an approach first developed for South America (Sayre and others, 2008), we modeled the standardized, mesoscale ecosystems of the conterminous United States by using a deductive, biophysical stratification of the region and associating the physically distinct areas with known distributions of vegetation assemblages. This approach emphasizes the multifactor mapping of ecosystems by their structure components and incorporates a characterization of the bioclimate regime and the geomorphology. Bailey (1996) illustrated an ecosystem at any point as the vertical integration of climate, landform, biota, surface and subsurface waters, soil, and bedrock (fig. 1), and it follows from this definition that ecosystem distributions vary spatially because of geographic variation in their major structure elements. Standardized ecosystems can therefore be mapped as the geospatial integration of these fundamental ecosystem structure elements across geographic space (Sayre and others, 2008), where ecosystem boundaries represent area-based changes in the structure components. This approach is essentially a geographic application of gradient analysis (Choesin and Boerner, 2002), where species distributions and abundances are related to environmental gradients in variables such as temperature and water, light, and nutrient availability.

\section{Deductive and Inductive Approaches to Ecosystem Modeling}

The approach presented herein emphasizes the mapping of NatureServe's (Comer and others, 2003) ecosystems by the mapping and spatial integration of their major structure elements and is accomplished through a comprehensive biophysical stratification of the conterminous United States

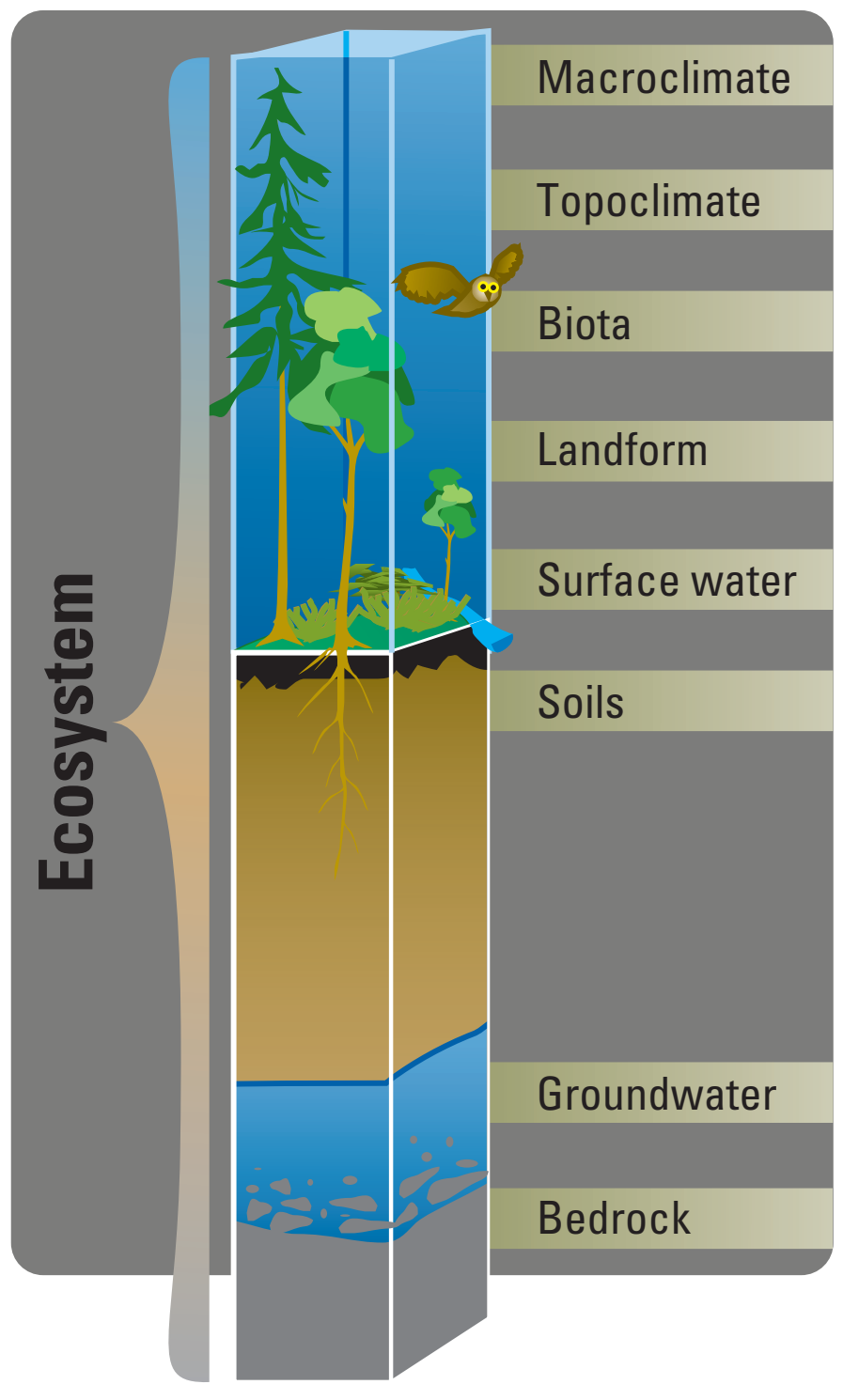

Figure 1. The vertical structure of an ecosystem, showing the spatial integration of biological and nonliving components. Reproduced with permission from Robert G. Bailey (1996).

into physically distinct areas. These unique physical environments are considered as the fundamental building blocks of ecosystems and have been referred to as "tesserae," or basic landscape elements (Huggett, 1995). This is a top-down, deductive modeling approach to mapping previously classified and described ecosystems.

It is also possible to map ecosystems by using a bottomup, inductive modeling approach, and concurrent efforts are underway to predictively map the same NatureServe ecosystems utilized in this study by using point-source data from over 100,000 locations. The U.S. Geological Survey Gap Analysis Program, which is part of the collaborative U.S. Gap Analysis Program (Scott and others, 2001), and the multiagency LANDFIRE Program (Ryan and others, 2006) are both using inductive modeling to map the current distribution 
of NatureServe ecosystems using point data sources where environmental attributes at points are associated with known ecosystem occurrences at those locations. The inductive modeling efforts are data intensive, and more than 100,000 points have been used to date. The degree of spatial concordance in the two sets of results will be assessed to help evaluate the utility of using the less data-intensive deductive method to map global ecosystems.

\section{Methodology}

Ecosystems classification.-Terrestrial ecological systems for the conterminous United States have been defined by NatureServe as spatially co-occurring assemblages of vegetation types sharing a common underlying substrate, ecological process, or gradient (Comer and others, 2003). The ecological systems are described in the NatureServe Explorer database (NatureServe, 2008). This classification uses diagnostic classifiers such as climate type, topographic position, and substrate type to characterize upland and wetland ecosystems at typical geographic scales of tens to thousands of hectares. Each ecosystem type exhibits one of four spatial patterns on the landscape: matrix forming, large patch, small patch, or linear. The matrix-forming types typically dominate regional landscapes, responding to climatic pattern at regional scales. Large-patch ecosystems are generally driven by natural disturbances within the regional matrix. Small-patch types are typically constricted in their location by physical factors such as a bedrock outcropping or soil moisture regime. Linear ecosystems typically form where local environments and ecological dynamics produce linear patterns, such as in coastal zones or along river corridors.

NatureServe's ecosystem classification followed the initial development of the National Vegetation Classification (NVC) (Grossman and others, 1998; NatureServe, 2008), which was established by the Federal Geographic Data Committee as the reporting standard to be used by Federal agencies for vegetation description and assessments (Federal Geographic Data Committee, 1997, 2008). Difficulty in mapping vegetation units at the finest levels (vegetation alliances and associations) of the NVC (Comer and others, 2003) and an interest in relating vegetation units to their natural biophysical setting led to an effort to aggregate spatially co-occurring vegetation units from the NVC into a new ecosystem classification (Comer and others, 2003). This ecosystem classification system has been adopted as the classification framework for various agency efforts, such as the U.S. Geological Survey (USGS) Gap Analysis Program (Scott and others, 2001) and the multiagency fire management program, LANDFIRE (Ryan and others, 2006), and NatureServe is considered a credible authority for providing the Federal Government with biodiversity information (USDA Forest Service, 2006b, p. 26). At the time of this writing, 690 terrestrial ecosystems have been described for the conterminous United States.
Mapping approach.-Ecosystems were mapped as physically distinct areas on the basis of biogeography, bioclimate, surficial materials lithology, landform, and topographic moisture potential. National raster data layers for each of these ecosystem structure elements were derived using best available data sources. The spatial resolution of the source data used to develop the input data layers varied considerably. For landforms and topographic moisture potential, the national datasets were developed at a relatively fine spatial resolution of 30 meters (m). The bioclimates data layer was derived from meteorological data having a resolution of 1 square kilometer $\left(\mathrm{km}^{2}\right)$, and the biogeographic regions data layer was derived from source data having the same resolution. The lithology dataset was compiled at a spatial resolution of $15 \mathrm{~km}^{2}$. All datasets were reconciled to a common 30-m raster data surface for the conterminous United States.

All input data layers were spatially combined, in a hierarchical sequence, to develop a comprehensive biophysical stratification of the conterminous United States by biogeography, bioclimate, surficial materials lithology, landform, and topographic moisture potential. This union produced the set of unique physical environments that represent the essential building blocks, or structure units, of ecosystems. These ecosystem structure units were subsequently aggregated and labeled with an ecosystem code from the NatureServe classification. Spatial pattern was included in the analysis to determine the sensitivity of the ecosystem delineation model to ecosystem size and spatial pattern. Source data, methods, and a graphical depiction of each of the input data layers follow. A schematic of the input data layers and their spatial combination to produce ecosystems is depicted in figure 2 .

Biogeographic regions.- -NatureServe's ecological divisions of the United States (Comer and others, 2003) were used to stratify the conterminous United States into 12 subcontinental biogeographical units (fig. 3). These units reflect broadscale homogeneity in vegetation distributions as a product of climate, phytogeographic history, disturbance regimes, and geographic isolation. These units thus reflect major, recognized phytogeographic distributions (Takhtajan, 1986).

Bioclimate regions. - Bioclimate regime strongly influences the differentiation and distribution of terrestrial ecosystems and is one of the key input layers in the ecosystem delineation process. Mesoscale isobioclimate regions (fig. 4) were identified as areas with homogeneity in ombrotype (wet/dry gradient) and thermotype (hot/cold gradient). These regions were mapped by using the DayMet data, a set of meteorological raster data surfaces for the Nation having a spatial resolution of $1 \mathrm{~km}^{2}$ (Thornton and others, 1997). These data layers were constructed from spatial interpolations of daily temperature, precipitation, radiation, and humidity data collected from meteorological stations over an 18-year period (1980-1997). The methodology used to produce the isobioclimate classes (Rivas-Martinez and Rivas y Sáenz, 2009) was derived from a consideration of bioclimatology and its relationship to phytogeography.

This approach develops a number of bioclimatic indices calculated from a variety of data on temperature and 


\section{Geospatial Approach-Terrestrial Ecosystems Mapping}

Input Layers

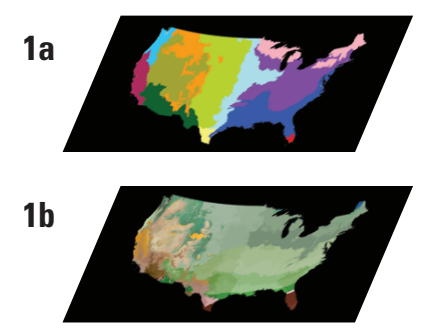

Biogeographic Region

(12 classes)

$$
+
$$

Isobioclimates

(127 classes)

\author{
Products
}
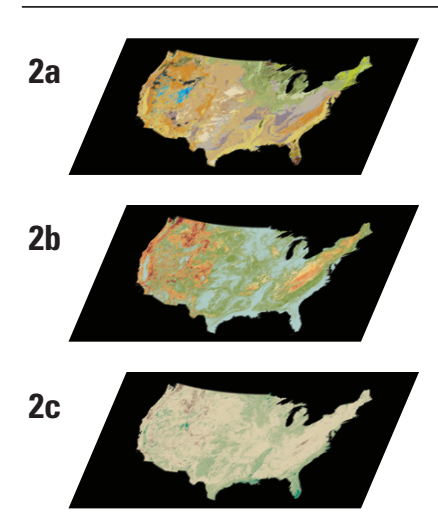

Surficial Materials Lithology

(17 classes)

$+$

Land Surface Forms

(10 classes)

$+$

Topographic Moisture Potential

(4 classes)

\section{Product 1}

Mesoscale Bioclimate/Biogeographic Regions

(435 classes)

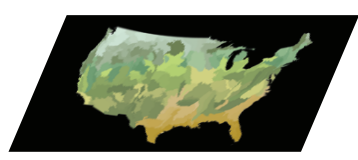

ECOMAP Sections

(for aggregation and labeling support)

$\begin{array}{lc}\text { Product } 3 & \\ \text { Ecosystem } & \text { aggregation and } \\ \text { Footprints } & \text { labeling }\end{array}$

(13,482 classes $)$

\section{Product 4 \\ NatureServe Ecosystems}

(419 classes)

Figure 2. Schematic depiction of the geospatial modeling approach to terrestrial ecosystems mapping, identifying the input data layers, the combination sequence, and resulting products for the conterminous United States.

precipitation (such as average temperature of the coldest month, total precipitation of the warmest 4-month period, a continentality index, and a thermicity index). The values of these indices are compared with established thresholds for the differentiation of thermotypic (hot/cold gradients) and ombrotypic (wet/dry gradients) regions, and the results are used in sets of decision rules to identify classes. The classification is implemented in four levels: macrobioclimates, bioclimates, thermotypes (thermoclimatic belts), and ombrotypes (ombroclimatic belts). The final isobioclimates dataset represents areas of distinct thermotype and ombrotype; 127 of these isobioclimates were mapped for the conterminous United States.

Surficial materials lithology.-Different substrate types at the Earth's surface influence distinct vegetation distributions at local, regional, and continental scales (Kruckeberg, 2002), underscoring the importance of including lithology as a primary structure element of ecosystems. A surficial materials dataset produced by the USGS for the conterminous United States (Soller and Reheis, 2004) was used as the source lithology data layer for the ecosystem mapping. These lithology classes were derived from a consideration of texture, internal structure, thickness, and environment of deposition or formation of surficial materials (Soller and Reheis, 2004) and were compiled from bedrock and soils maps at a scale of 1:5,000,000. This surficial materials map depicts broadly defined common map units for the purpose of providing an overview of the existing data and knowledge. The lithology classes from this data layer were aggregated into a set of 17 ecologically meaningful lithologies and mapped (fig. 5) as key substrates that typically control or influence the distribution of terrestrial ecosystems.

Land surface form classes.-Regional physiography and land surface forms strongly influence the differentiation and distribution of terrestrial ecosystems, and the landform input layer is a key part of the ecosystem delineation process. Nine landform classes (flat plains, smooth plains, irregular plains, escarpments, low hills, hills, breaks/foothills, low mountains, and high mountains/deep canyons) were topographically 


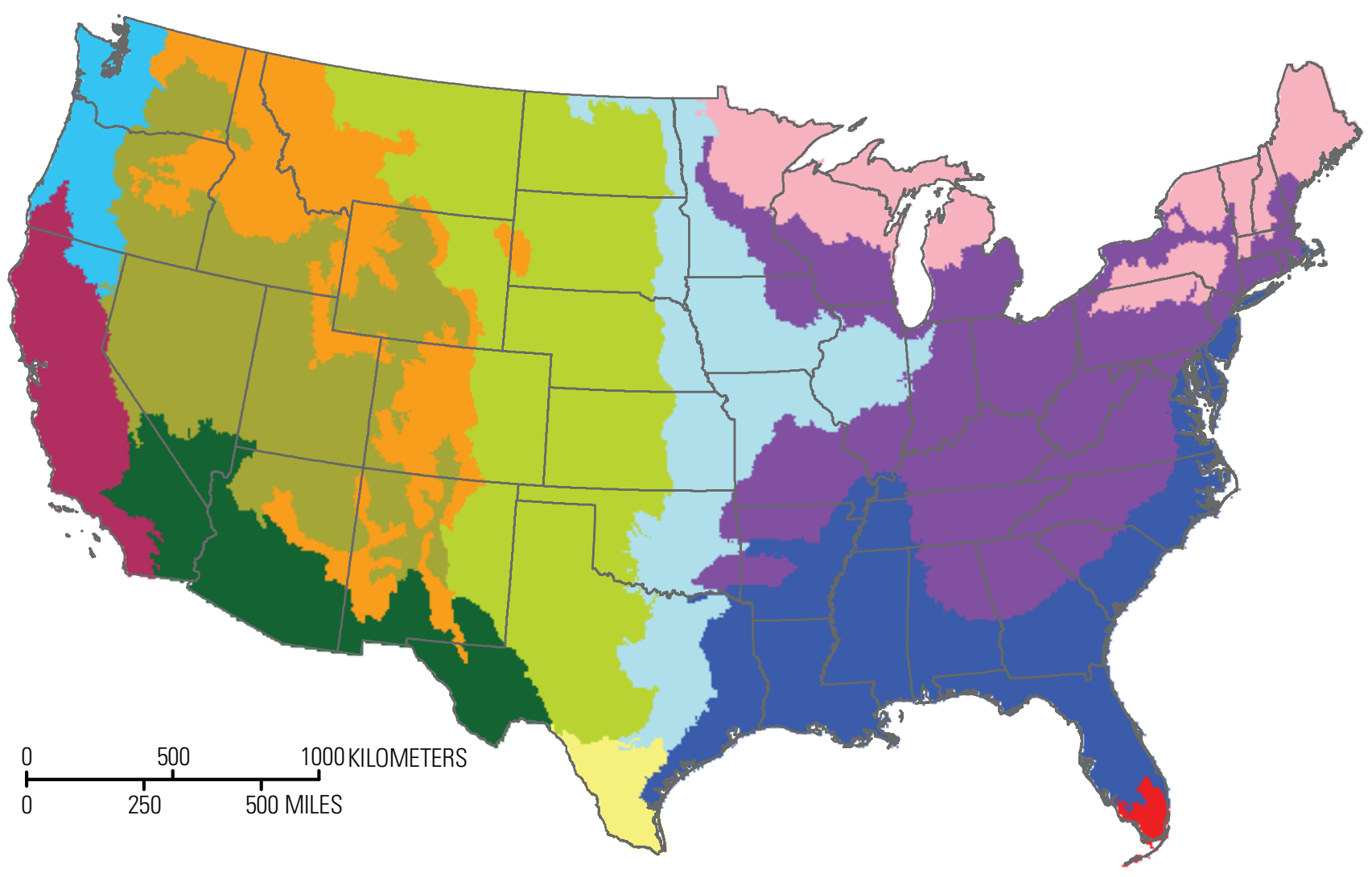

\section{Biogeographic Regions - NatureServe Ecological Divisions}
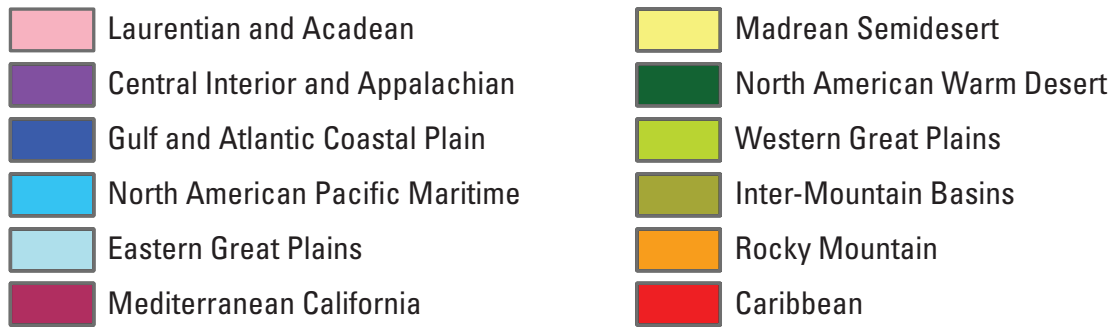

Figure 3. Map of the conterminous United States showing NatureServe's ecological divisions (Comer and others, 2003), modified from Bailey (1998b) and identifying broad areas of phytogeographic similarity (general homogeneity of vegetation assemblages). The homogeneity is due to evolutionary history, geographic isolation, disturbance history, and climate.

modeled from combinations of slope class and local relief (fig. 6). The methodology used to produce these land surface form classes built on the approach of Dikau and others (1991) to automate land surface form classification by using a digital elevation model and was developed by the Missouri Resource Assessment Partnership (MoRAP). The MoRAP approach used a moving neighborhood analysis window and a land surface classification method modified from Hammond (1964). The USGS 30-m National Elevation Dataset (Gesch, 2007) was the data source, and a $1-\mathrm{km}^{2}$ window was used for neighborhood analysis (True and others, 2000; True and MoRAP Staff, 2002).
Whereas Hammond's methodology was based on three variables, slope, local relief, and profile type, MoRAP's methodology used only slope and local relief (True and MoRAP Staff, 2002). Slope was classified as gently sloping or not gently sloping by using a slope threshold of 8 percent. Local relief was divided into five classes $(0-\leq 15 \mathrm{~m},>15-\leq 30 \mathrm{~m}$, $>30-\leq 90 \mathrm{~m},>90-\leq 150 \mathrm{~m}$, and $>150 \mathrm{~m}$ ). Slope classes and relief classes were subsequently combined to produce eight land surface form classes (flat plains, smooth plains, irregular plains, escarpments, low hills, hills, breaks/foothills, and low mountains). A ninth class, high mountains/deep canyons, was added to the landform classification by using an additional 


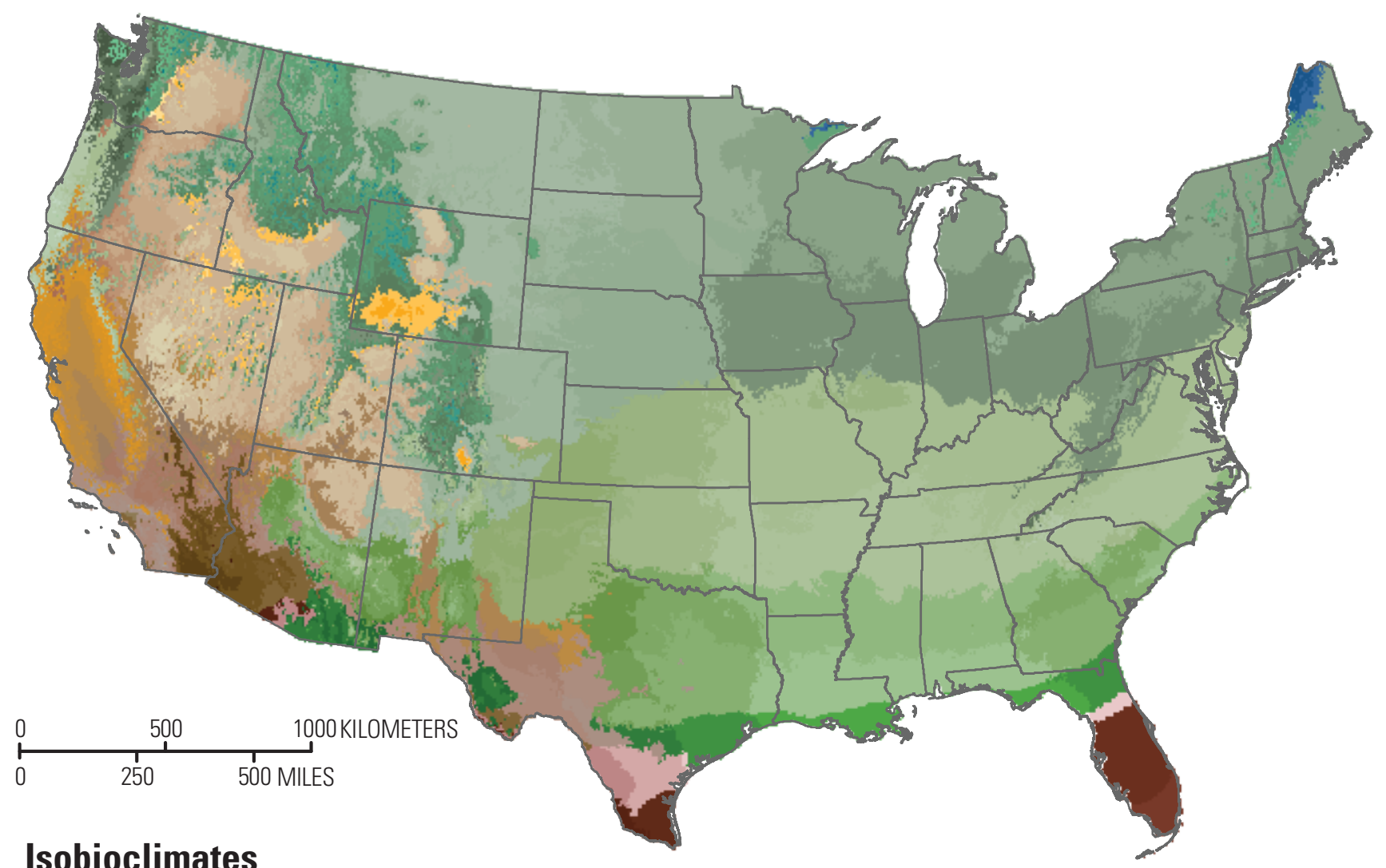

\section{Isobioclimates}

\section{Tropical Thermotypes}
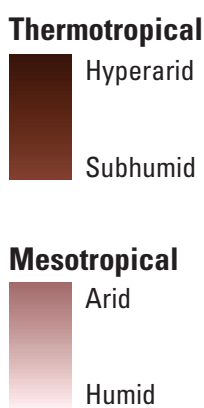

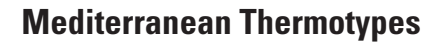

Inframediterranean
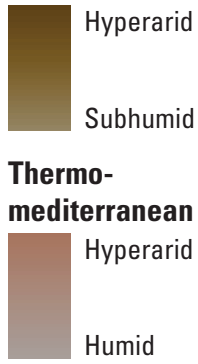

Mesomediterranean

Arid
Hyperhumid

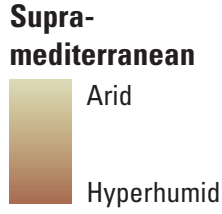

Oromediterranean

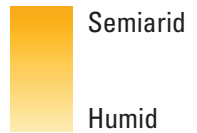

Temperate Thermotypes

Infra-

temperate

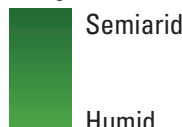

Thermo-

temperate

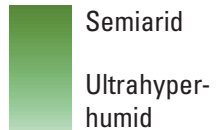

Mesotemperate

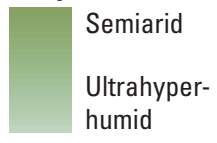

Supra-

temperate

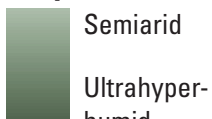

humid

Oro-

temperate

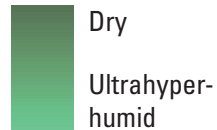

Cryoro-

temperate

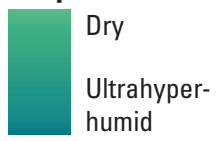

\section{Boreal Thermotypes}
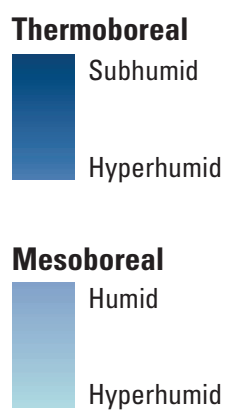

\section{Supraboreal}

Hyperhumid

Figure 4. Map of the conterminous United States showing mesoscale isobioclimate regions, representing areas of distinct ombrotype (wet/dry gradients) and thermotype (hot/cold gradients) regimes; 127 isobioclimates were identified and mapped.

local relief class $(>400 \mathrm{~m})$. The relations among slope, relief, and landform class are depicted in table 1 . The tenth landform class, drainage channels (wet or dry), was derived independently from the other classes by using the slope position algorithm (Weiss, 2001).
By use of the 30-m USGS National Elevation Dataset (Gesch, 2007) a topographic position index (TPI) was calculated; the TPI represents the difference between the elevation of a cell and the mean elevation of its neighborhood within a $1-\mathrm{km}^{2}$ moving window. Six slope position classes were 


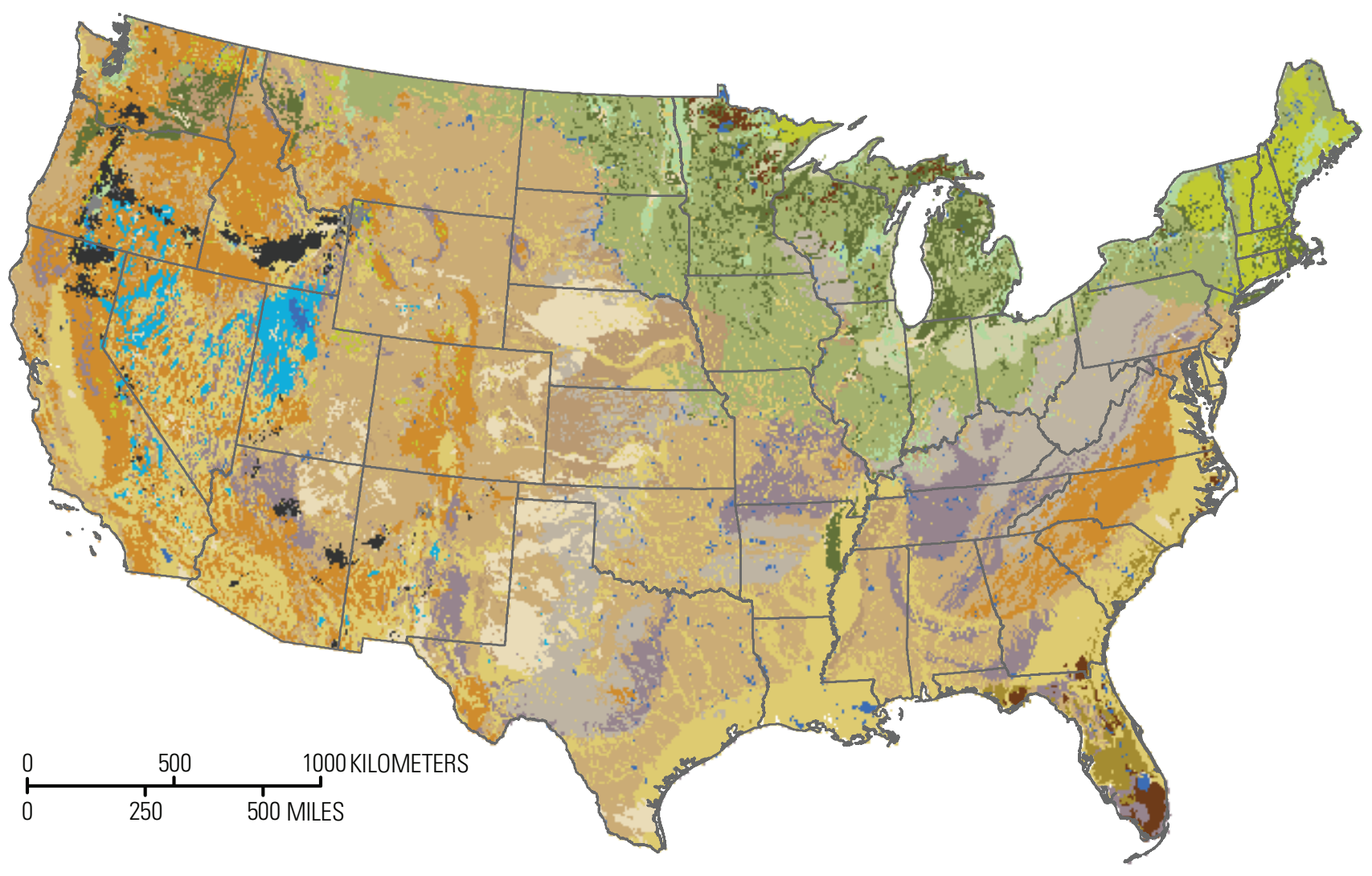

\section{Surficial Materials Lithology}

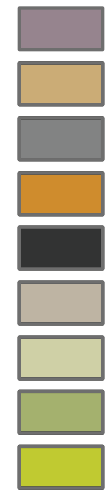

Carbonate Residual Material

Non-Carbonate Residual Material

Alkaline Intrusive Volcanic Rock

Silicic Residual Material

Extrusive Volcanic Rock

Colluvial Sediment

Glacial Till, Clayey

Glacial Till, Loamy

Glacial Till, Coarse-Textured
Glacial Outwash and Glacial Lake Sediment, Coarse-Textured

Glacial Lake Sediment, Fine-Textured

Hydric, Peat and Muck

Eolian Sediment, Coarse-Textured (Sand Dunes)

Eolian Sediment, Fine-Textured (Glacial Loess)

Saline Lake Sediment

Alluvium and Fine-Textured Coastal Zone Sediment

Coastal Zone Sediment, Coarse-Textured

Water

Figure 5. Map of the conterminous United States showing lithology of surficial materials, depicting the distributions of 17 distinct substrate types.

identified by comparison of the TPI and the standard deviation of the neighborhood elevation (Weiss, 2001). Two of these slope classes, valleys and lower slopes, were combined to produce a drainage channels landform class, which was added to the other nine landform classes but was not shown in figure 6 .

Topographic moisture potential index.-The substrate moisture regime strongly influences the differentiation and distribution of terrestrial ecosystems (Bailey, 1996). Although isobioclimate maps characterize surface moisture potential on the basis of long-term precipitation patterns, the moisture potential at any point on the surface of the Earth is also a function of surface topography (accumulation of water), substrate porosity (drainage), and evapotranspiration (loss of moisture to atmosphere).

To better account for surface moisture potential, a topographic moisture potential index (fig. 7) was developed to distinguish potential wetlands from uplands on the basis of topographic setting. Surface moisture potential was derived from a combination of computed topographic characteristics and mapped wetlands boundaries. The source of data for 


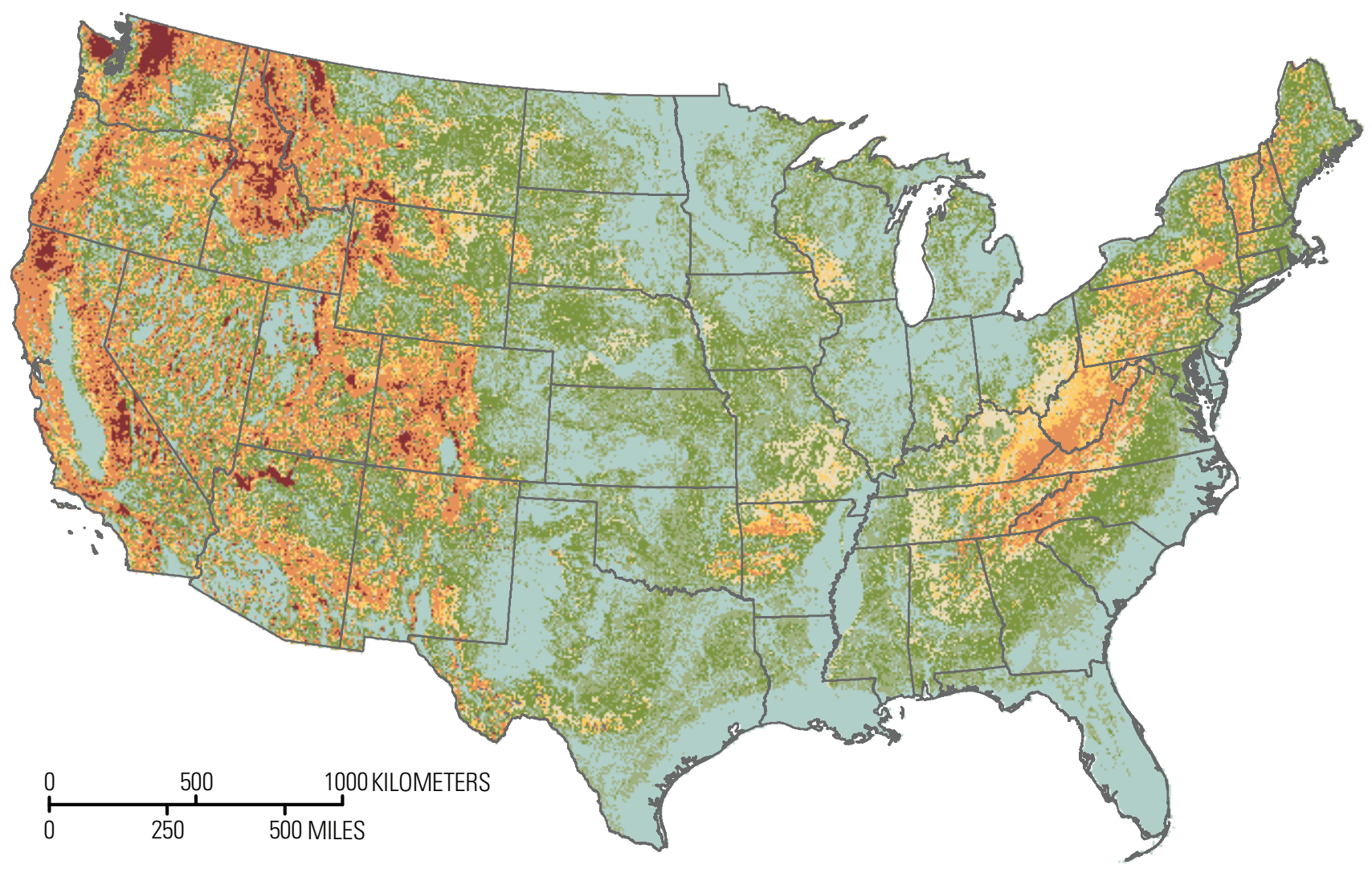

\section{Land Surface Forms}
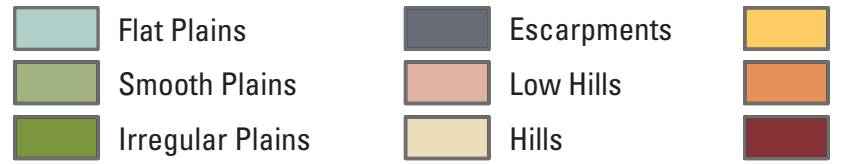

Breaks/Foothills

Low Mountains

High Mountains/Deep Canyons

Figure 6. Map of the conterminous United States showing landform classes modeled using 30-m digital elevation data and derived from neighborhood analyses of slope and relative relief.

this assessment is the nationwide Elevation Derivatives for National Applications (EDNA) dataset (Verdin, 2000; Franken and others, 2001). The 30-m EDNA hydrologic derivative database was derived from the USGS 30-m National Elevation Dataset (Gesch, 2007) and contains a national compound topographic index (CTI) data layer (http://edna.usgs.gov/ Edna/datalayers/cti.asp). The CTI is a topographically derived measure of the slope in a raster cell and the contributing area from "upstream" raster cells and thus expresses the potential for water flow to a point.

Potential accumulation at a point (CTI) was compared with independent estimates of water accumulation by obtaining geospatial data from a number of sample locations representing wetland/upland boundaries from the National Wetlands Inventory (NWI) dataset (U.S. Fish \& Wildlife Service, 2009). Where these "shorelines" (the interface between wetlands and adjacent land) occurred, the CTI values were extracted and a histogram of their statistical distributions was calculated. Subsequently, on the basis of an evaluation of these histograms, CTI thresholds were developed to separate potential wetlands from uplands. A similar process was used to assess the distributions of CTI values for known locations of mesic and dry uplands. After the range of CTI values for these three different substrate moisture regimes (potential wetlands, mesic uplands, and dry uplands) was determined, the CTI dataset was recalculated to identify the topographic moisture potential.

The final step in the generation of the data layer representing the national topographic moisture potential was to partition the dry uplands class into two subclasses, a dry uplands class and a very dry uplands class. As applicable to northern temperate latitudes, very dry uplands were defined as dry uplands with relatively steep, south-facing slopes, and identification of this class was based on the slope and aspect 
Table 1. Land surface form classes topographically modeled from combinations of slope class and local relief.

[The methodology to produce the land surface form classes was developed by the Missouri Resource Assessment Partnership (MoRAP); see True and MoRAP Staff (2002). km², square kilometer]

\begin{tabular}{ccl}
\hline \multicolumn{1}{c}{ Slope class } & $\begin{array}{c}\text { Local relief } \\
\text { (meters) }\end{array}$ & \multicolumn{1}{c}{$\begin{array}{c}\text { Land surface } \\
\text { form class }\end{array}$} \\
\hline $\begin{array}{l}\text { Gently sloping-Slope }<8 \text { percent } \\
\text { in more than 50 percent of area }\end{array}$ & $\leq 15$ & Flat plains \\
in 1-km² neighborhood. & $>15-\leq 30$ & Smooth plains \\
& $>30-\leq 90$ & Irregular plains \\
& $>90$ & Escarpments \\
Not gently sloping-Slope $<8$ & $\leq 30$ & Low hills \\
percent in less than or equal \\
to 50 percent of area in 1-km² \\
neighborhood. & $>30-\leq 90$ & Hills \\
& $>90-\leq 150$ & Breaks/foothills \\
& $>150-\leq 400$ & Low mountains \\
& $>400$ & High mountains/ \\
& & deep canyons. \\
\hline
\end{tabular}

datasets derived from the USGS 30-m National Elevation Dataset. The final topographic moisture potential dataset for the conterminous United States contains four classes: potential wetlands, mesic uplands, dry uplands, and very dry uplands.

Ecosystem labeling process.-The ecosystem "footprints" (ecosystem structure units) resulting from the union of the input layers described above characterize the physical potential of the environment and represent the building blocks that were attributed with NatureServe ecosystems labels. The labeling process was semiautomated and iterative and was accomplished by ruleset formulation and subsequent spatial implementation of these rules using the ecosystems footprint data. The rulesets were derived independently of the mapping effort in an expert-knowledge-based process. A labeling rule was developed for each NatureServe ecosystem, associating it with a particular biogeographic region, bioclimate, lithology, landform, and topographic moisture potential. The rulesets were organized as a matrix of ecosystem types and their attribute classes, and the matrix was used as a labeling look-up table in the geographic information system (GIS). The rulesets were developed by the principal author of the ecosystems classification (Comer and others, 2003) on the basis of the published ecosystem descriptions and known locations of vegetation assemblages. Rulesets were iteratively revised after each implementation of the spatial model. Four iterations were implemented to conclude the labeling process.

\section{Results}

The five input data grids were combined to produce the ecosystems footprints data layer for the conterminous
United States. This product is essentially a characterization of physically distinct areas at a base resolution of $30 \mathrm{~m}$ and in a digital data format and, as such, describes the physical geography of the conterminous United States in a manner heretofore unavailable. The integration of the five input data layers produced 49,168 unique combinations of biogeography, bioclimate, lithology, landform, and topographic moisture potential. Of these unique footprint types, 13,482 met a minimum pixel count threshold (20,000 pixels) and were used in the labeling process. The threshold value of 20,000 pixels was chosen because the sum of the area from all footprints with pixel counts under this value was less than 1 percent of the total area being mapped. Excluding open water, 98.7 percent of the footprint pixels were classified as terrestrial ecosystem types, and the remaining 1.3 percent of pixels were classified as unknown.

During the labeling process, the 13,482 ecosystem footprints were associated with a NatureServe ecosystem type. This labeling process was aggregative, illustrating the primarily many-to-one (multiple ecosystem footprints to one unique ecosystem) nature of the data. However, several one-to-many (one unique footprint type for multiple ecosystem types) relationships were also observed in the labeling process. In these instances, the same physical environment could support different vegetation assemblages in different parts of the country, likely as a result of a different evolutionary history. These one-to-many relationships were resolved by incorporating into the analysis a finer biogeographic data layer, consisting of units from the USDA Forest Service's ECOMAP sections (Cleland, Freeouf, and others, 2005). The sections data were not spatially combined with the footprints dataset but were incorporated into the labeling process through ruleset revisions. The decision to use ECOMAP sections to increase the biogeographic resolution of the analysis was based on the availability of information on the presence or absence of NatureServe ecosystems in ECOMAP sections.

The ecosystem structure footprints were aggregated into 419 terrestrial ecosystems (fig. 8). This product represents a new map of standardized, replicable, mesoscale terrestrial ecosystems for the conterminous United States. The 419 ecosystems mapped through this process represent 60 percent of the total number of ecosystems (690) described for the conterminous United States at the time of this writing. To convey a sense of the types, numbers, and distributions of ecosystems in a local to regional context, figure 9 presents a map of these ecosystems in a $6,000-\mathrm{km}^{2}$ area in northeastern Utah.

As would be expected from their generally larger size, most of the ecosystems mapped ( 72 percent) were either matrix-forming or large-patch ecosystems, as opposed to the smaller linear and small-patch ecosystems, and the method discriminated 70 percent of the total number of larger ecosystems (matrix and large patch), but only 47 percent of the smaller ecosystems (linear and small patch). The deductive modeling approach appears to be robust for the delineation of these larger ecosystem types but limited in the resolution of small-patch and linear ecosystems. 


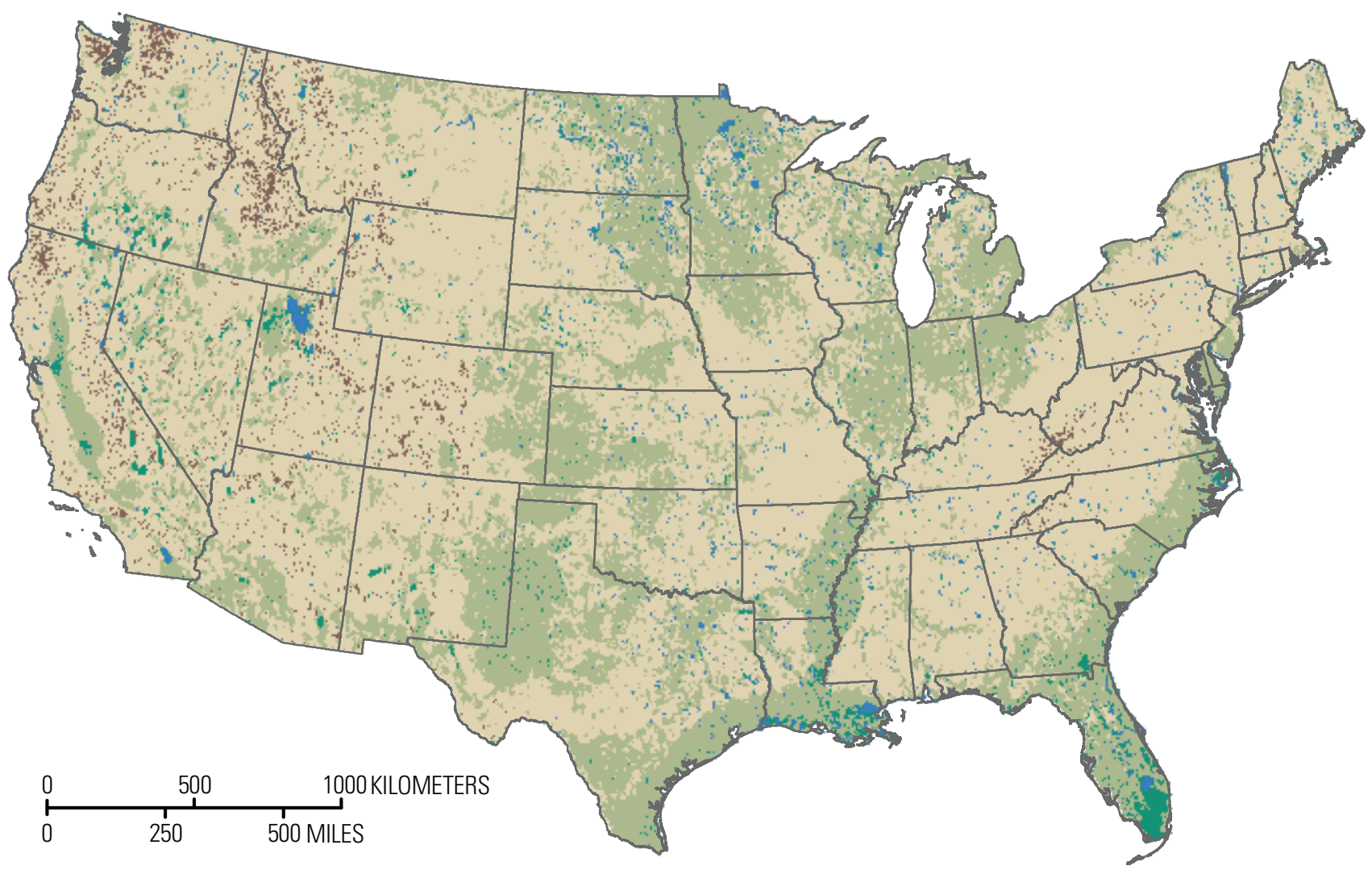

\section{Topographic Moisture Potential Classes}

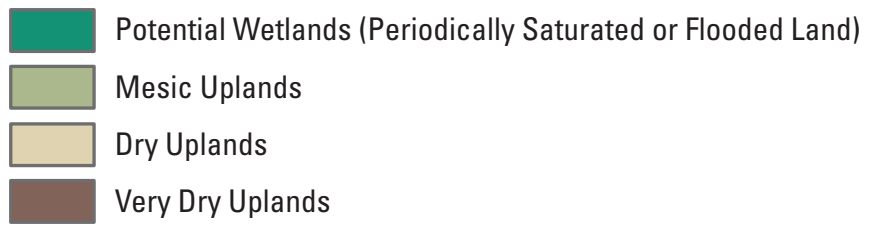

Water

Figure 7. Map of the conterminous United States showing topographic moisture potential index modeled using 30-m digital elevation data and derived from analyses of potential accumulation of moisture at a point based on topography.

\section{Discussion}

The mapped ecosystem distributions presented herein should be regarded as potential, rather than actual. They should be interpreted as the probable vegetation assemblages that would be expected to occur as a biotic response to the physical potential of the environment, in the absence of significant human disturbance. Mapping the probable distributions of potential ecosystems has a particular utility for ecosystem restoration, as it characterizes expected (historical) biotic responses to the physical environment. Much of the conterminous United States has been subject to considerable land cover change (Loveland and others, 2002), and what is mapped in this study as a potential ecosystem type may in fact be developed or in agricultural use. In a future analysis, impervious surfaces and other altered landscapes will be masked out to determine the probable distribution of actual, rather than potential, ecosystems.

The accuracy of the ecosystem map is currently being evaluated. Ideally, a national field campaign would be conducted to assess the accuracy of the input layers as well as the final ecosystem map at a randomly selected set of points representing each of the 419 ecosystem types. Such an 


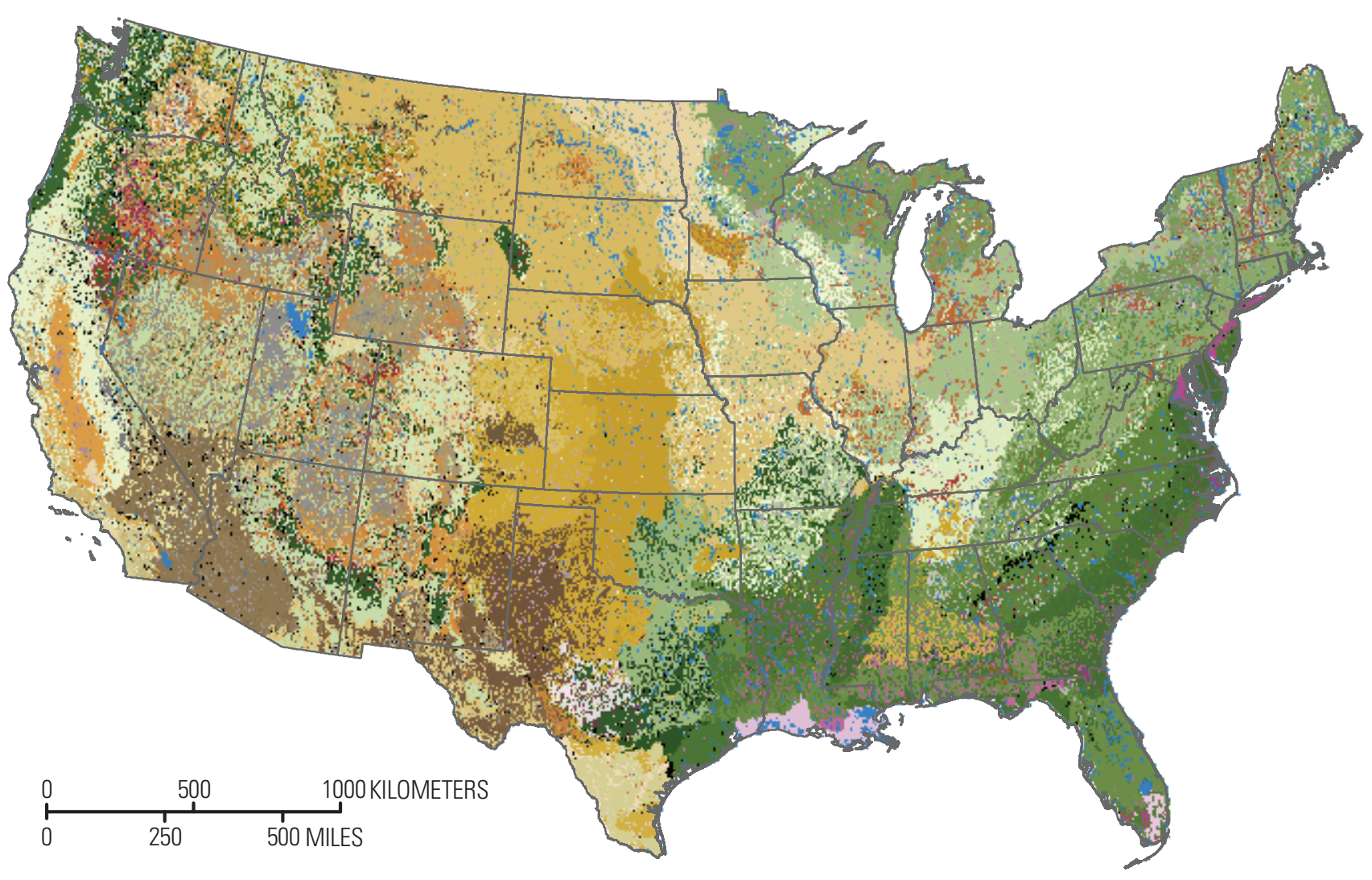

\section{Terrestrial Ecosystems}

\begin{tabular}{|l|l}
\hline & Forest and Woodland Ecosystems \\
& Herbaceous Ecosystems \\
\hline \hline & Shrubland Ecosystems \\
Steppe/Savanna Ecosystems
\end{tabular}

Woody Wetland Ecosystems

Herbaceous Wetland Ecosystems

Sparsely Vegetated Ecosystems

Figure 8. Map of the conterminous United States showing terrestrial ecosystems that were deductively modeled through biophysical stratification of the area into ecosystem footprints (physically distinct areas) and subsequent attribution of these footprints with a NatureServe ecosystem type. For this map, 419 NatureServe ecosystems were mapped, each with multiple spatial occurrences; in the figure explanation, the ecosystems are shown grouped by general biome categories. Figure 9 shows some of these ecosystems in more detail for a small area in Utah.

assessment is beyond the scope of the current effort. However, the USGS Gap Analysis Program (GAP) and the multiagency LANDFIRE Program each have considerable amounts of point location data, with both environmental and ecosystem type attributes. When the GAP and LANDFIRE inductive modeling efforts are complete for the conterminous United States, the results from the deductive method and those inductive modeling methods will be compared. Planning is underway for a collaboration to assess both (1) the accuracy of the ecosystem data presented herein using in situ data and (2) the spatial concordance between the ecosystem maps resulting from the deductive and the inductive modeling methods. The top-down, deductive model described herein is currently planned (Sayre and others, 2007) as the method for mapping standardized, robust, and practical global ecosystems as an ecosystems and biodiversity program (Muchoney, 2008) of the Global Earth Observation System of Systems (GEOSS), an intergovernmental protocol commissioned by the Group on Earth Observations (2005).

It should be emphasized that although the NatureServe ecosystem classification was used as the target classification for this work, other ecological unit classifications could be 


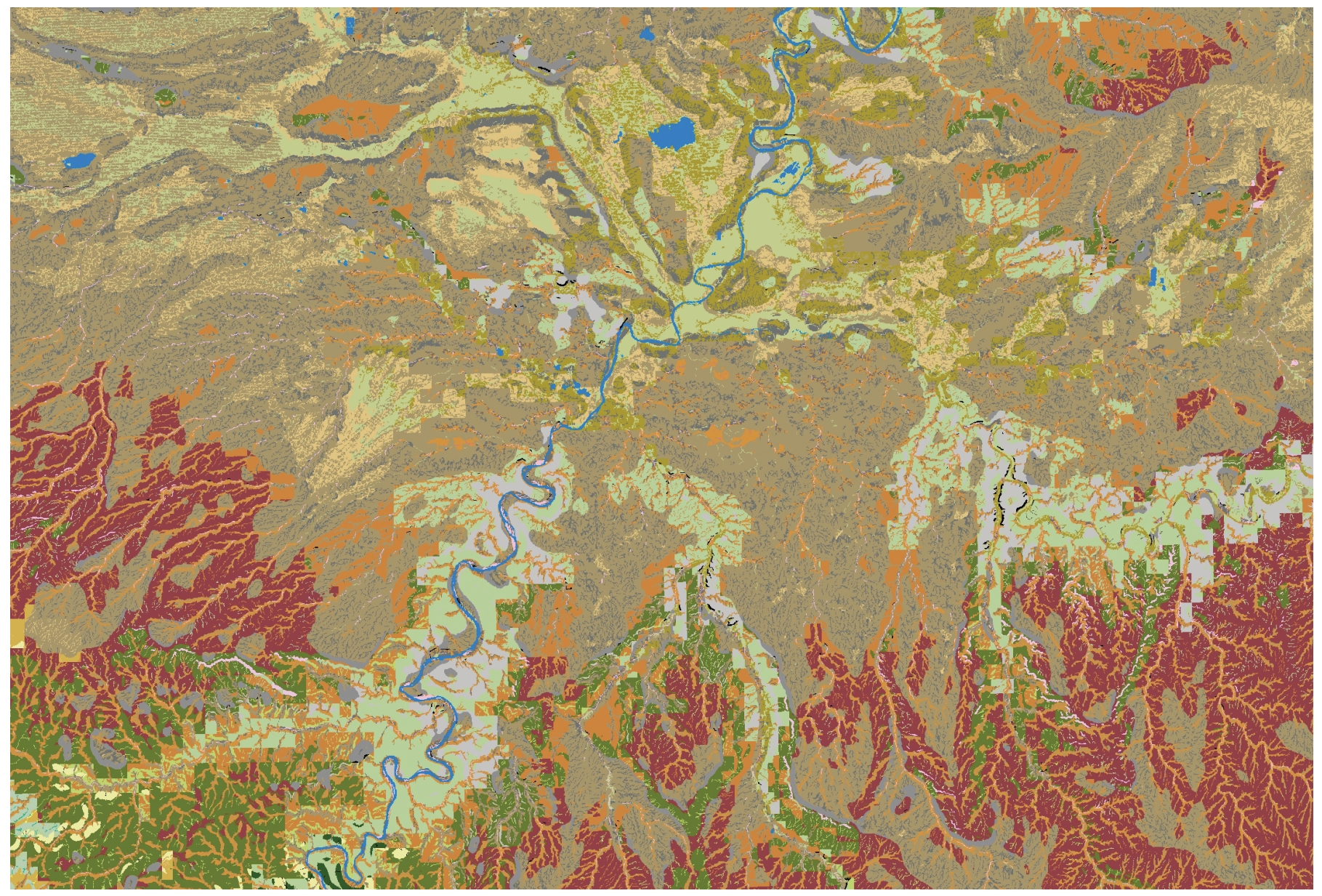

\section{Terrestrial Ecosystems}

Colorado Plateau Mixed Bedrock Canyon and Tableland

Colorado Plateau Mixed Low Sagebrush Shrubland

Colorado Plateau Pinyon-Juniper Shrubland

Colorado Plateau Pinyon-Juniper Woodland

Columbia Plateau Silver Sagebrush Seasonally Flooded Shrub-Steppe

Great Basin Foothill and Lower Montane Riparian Woodland and Shrubland

Great Basin Pinyon-Juniper Woodland

Great Basin Semi-Desert Chaparral

Inter-Mountain Basins Aspen-Mixed Conifer Forest and Woodland

Inter-Mountain Basins Big Sagebrush Shrubland

Inter-Mountain Basins Big Sagebrush Steppe

Inter-Mountain Basins Cliff and Canyon

Inter-Mountain Basins Greasewood Flat

Inter-Mountain Basins Juniper Savanna

Inter-Mountain Basins Mat Saltbush Shrubland

Inter-Mountain Basins Montane Sagebrush Steppe

Inter-Mountain Basins Semi-Desert Grassland

Inter-Mountain Basins Semi-Desert Shrub-Steppe

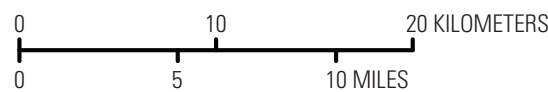

Inter-Mountain Basins Shale Badland

Middle Rocky Mountain Montane Douglas-Fir Forest and Woodland

North American Arid West Emergent Marsh

Rocky Mtn. Cliff, Canyon, and Massive Bedrock

Rocky Mtn. Lodgepole Pine Forest

Rocky Mtn. Lower Montane-Foothill Riparian Woodland and Shrubland

Rocky Mtn. Poor-Site Lodgepole Pine Forest

Rocky Mtn. Subalpine Dry-Mesic Spruce-Fir Forest and Woodland

Rocky Mtn. Subalpine-Montane Riparian Shrubland

Southern Rocky Mtn. Dry-Mesic Montane Mixed Conifer Forest and Woodland

Southern Rocky Mtn. Mesic Montane Mixed Conifer Forest and Woodland

Southern Rocky Mtn. Montane-Subalpine Grassland

Southern Rocky Mtn. Ponderosa Pine Savanna

Southern Rocky Mtn. Ponderosa Pine Woodland

Wyoming Basins Dwarf Sagebrush Shrubland and Steppe

Water

Figure 9. Map showing terrestrial ecosystems in a 6,000- $\mathrm{km}^{2}$ section of northeastern Utah and depicting the types, numbers, and spatial patterns of ecosystems at a local to regional scale. 
used as the set of possible labels for aggregating the footprints. An interesting exercise would be to aggregate the ecosystem footprints into local or regional ecosystem classifications through the development of appropriate labeling rulesets as was done here for the NatureServe classification. The NatureServe ecosystems classification strongly emphasizes vegetation distributions and is itself built from a reconfiguration of the National Vegetation Classification, and so the mapped ecosystems presented herein are quite biological in nature. It would be possible to aggregate the footprints in another manner that more strongly emphasized geo-ecosystems (Huggett, 1995), rather than bio-ecosystems.

It should also be emphasized that these ecosystems were mapped from a spatially explicit consideration of their structure elements. Proponents of holistic ecosystem ecology maintain that ecosystems cannot be fully understood through reductionist approaches and caution that reducing ecosystems to their abiotic and biotic components does not sufficiently explain the causes and dynamics of spatial ecosystem patterns (Li, 2000). However, processes associated with ecosystem function (such as cycling of water, energy, and nutrients (Bormann and Likens, 1979)), as well as emergent ecosystem properties (such as self-organization and directionality (Salt, 1979)), were not considered as primary delineation elements, as these functions and properties are not readily mappable. Moreover, this mapping approach is entirely vertical and does not use data on lateral flows (for example, of water, nutrients, or energy) associated with key ecosystem processes, again owing to difficulties in conceptualizing and mapping those flows at mesoscales over the entire conterminous United States. Although ecosystem function is indirectly considered in the model in certain cases (for example, where firedependent vegetation occurs on dry, exposed substrates or where linear riparian ecosystems form along river corridors), it is not included in the geospatial analysis. The method used here to map ecosystem distributions by spatially delineating and integrating their structure components across geographic space will be subject to refinement in the future as innovative approaches for mapping ecosystem function and processes over large areas are further developed.

The new national datasets for bioclimates, surficial materials lithology, landforms, and topographic moisture potential index were produced as initial, robust representations of the primary structure elements of ecosystems and are best considered as rigorous and appropriate input data layers for geospatial ecosystem delineation, rather than as exhaustive treatments of those themes. Nevertheless, these intermediate products may be useful for other applications (such as engineering, land capability analysis, resource management, and biodiversity conservation), and their utility for those applications should be considered and evaluated.

Two very important lessons were learned from this work, which need to be considered in future applications of this ecosystem mapping methodology. First, the use of multiple input datasets of variable spatial resolution, although necessary to incorporate the best available data, was somewhat problematic. For example, the landforms data, derived from the USGS 30-m National Elevation Dataset, produced relatively fine, dispersed, geomorphological structures. However, the coarser, more regional scale lithology data might indicate the same lithology for all these distinct landforms, which may have ranged from plains to mountains. Moreover, an edge effect (imperfect alignment of superimposed layers) was often noted when comparing the boundaries of lithological features and other inputs. A possible solution to this problem in the future might include the development of a geostatistical attribution procedure for assigning a "most probable" attribute from the coarser dataset (geology) to the features mapped with finer resolution data (landforms), especially in cases where a direct relationship between the two has been identified.

Secondly, more biogeographic specificity was necessary to discriminate ecosystems than was originally planned. The original 12 ecological divisions used in the stratification were inadequate to resolve the one-footprint-to-many ecosystems cases, and it was necessary to add a finer level biogeographic unit in the labeling step. In the future, incorporating a much finer biogeographic unit than, for example, a continental-scale subdivision, is recommended.

\section{Conclusion}

New national classifications and maps were developed for bioclimates, surficial materials lithology, landforms, and topographic moisture potential index, and these were combined to map distinct physical environments at the finest spatial resolution yet attempted. These ecosystem footprints were then deductively associated with previously classified and described ecosystems, and a new map of 419 terrestrial ecosystems was produced for the conterminous United States with a $30-\mathrm{m}$ cell size. This ecosystems map provides an initial, comprehensive, and consistent delineation of standardized terrestrial ecosystems across the conterminous United States at a resolution considerably finer than existing ecoregionalizations of the area (Omernik, 1987; Bailey, 1996; Commission for Environmental Cooperation, 1997; Ricketts and others, 1999; Groves and others, 2000).

This ecogeographic regionalization approach closely follows the disciplinary emphasis of ecosystem geography (Bailey, 1996) and the geoecosystems concept (Huggett, 1995). The approach was more successful in delineating the larger matrix-forming and large-patch ecosystems than the small-patch and linear ecosystems. The same physical environment could produce different biotic responses (vegetation assemblages), likely because of differences in evolutionary history, geographic isolation, and disturbance history. To separate different ecosystems occurring on similar abiotic templates, it was necessary to incorporate a finer grained biogeographic stratifier than was originally contemplated.

These new ecosystems show considerable promise for use in studies examining impacts on ecosystems from a 
number of sources (for example, climate change, invasive species, fire, and land cover change). Not only do they represent a standardized geospatial framework for the impact studies, but they are also the very entity experiencing the impacts, as opposed to some other entity or geography (such as watershed, land cover class, or pixel). The potential for climate change to alter the location and abundance of ecosystems in the future is more easily addressed through an understanding of the abiotic components that control ecosystem distributions. Similarly, the ecosystems could be useful for studies of the production and value of ecosystem goods and services (benefits), as the ecosystems are in fact the source of these benefits. There may be considerable utility in using the ecosystems, which are the very service provider units, as a standardized geographic accounting unit in assessments of ecosystem services. Finally, there is much promise in using the ecosystems as a standard unit for resource management and conservation. Federal agencies with a mandate to manage their land holdings with an ecosystem-based management approach, for example, would find a spatial delineation of the ecosystems in their jurisdictions helpful. Moreover, biodiversity conservationists with an interest in conserving representative examples of all unique ecosystems (Groves, 2003) may welcome the ecosystems dataset as a source of conservation targets (Redford and others, 2003) for planning and implementing conservation programs.

\section{Acknowledgments}

The authors would like to acknowledge many individuals who provided data, advice, method and product reviews, meeting support, analytical support, editing, and inspiration. We

appreciate the help from colleagues inside and outside the U.S. Geological Survey (USGS), and names are listed alphabetically below.

Robert Bailey, U.S. Forest Service

Mark Bauer, Parallel Inc.

Catherine Costello, USGS

Bryant Cramer, USGS

Lee DeCola, USGS

Jon Dewitz, USGS

Dave Diamond, University of Missouri

Tom DiNardo, USGS

Jeannette Foltz, USGS

Anna Glover, USGS

Marty Goldhaber, USGS

Elizabeth Good, USGS

Susan Goplen, USGS

Gregory Green, USGS

Andrea Grosse, U.S. Fish \& Wildlife Service (formerly USGS)

Jon Hak, NatureServe

Collin Homer, USGS

Bruce Jones, USGS

John Jones, USGS

Dave Kirtland, USGS
Annette Kulyk, USGS

Alexa McKerrow, USGS

John Mosesso, USGS

Doug Muchoney, USGS

Mark Myers, USGS

Tom Owens, USGS

Richard Pike, USGS

Sandra Poppenga, USGS

Salvador Rivas y Sáenz, Centro de Investigaciones

Fitosociológicas [Phytosociological Research Center]

Salvador Rivas-Martinez, Centro de Investigaciones

Fitosociológicas

Barbara Ryan, World Meteorological Organization (formerly USGS)

Lisa Scales, USGS

Sarah Shafer, USGS

Jonathan Smith, USGS

Dave Soller, USGS

Jeff Spooner, USGS

Mike Starbuck, USGS

Diane Stephens, USGS

Doug Stoeser, USGS

Ione Taylor, USGS

Alicia Torregrosa, USGS

Diane True, University of Missouri

Bea Van Horne, USGS

Jim Vogelmann, USGS

Andrew Weiss, Washington State Department of Fish and Wildlife

Stan Wilds, Parallel Inc.

Tom Winter, USGS

Alberto Yanosky, Guyra Foundation, Paraguay

Paul Young, USGS

Zhiliang Zhu, USGS

\section{References Cited}

Bailey, R.G., 1996, Ecosystem geography: New York, Springer-Verlag, 204 p., 2 pls. in pocket.

Bailey, R.G., 1998a, Ecoregions; The ecosystem geography of the oceans and continents: New York, Springer-Verlag, $176 \mathrm{p}$.

Bailey, R.G., 1998b, Ecoregions map of North America; Explanatory note: U.S. Department of Agriculture, Forest Service, Miscellaneous Publication no. 1548, 10 p., 1 map in pocket, scale 1:15,000,000.

Bormann, F.H., and Likens, G.E., 1979, Pattern and process in a forested ecosystem: New York, Springer-Verlag, 253 p.

Choesin, Devi, and Boerner, R.E.J., 2002, Vegetation boundary detection; A comparison of two approaches applied to field data: Plant Ecology, v. 158, no. 1, p. 85-96, doi:10.1023/A:1014720508155. 
Cleland, D.T., Avers, P.E., McNab, W.H., Jensen, M.E., Bailey, R.G., King, Thomas, and Russell, W.E., 1997, National hierarchical framework of ecological units, in Boyce, M.S., and Haney, A.W., eds., Ecosystem management; Applications for sustainable forest and wildlife resources: New Haven, Conn., Yale University Press, p. 181-200.

Cleland, D.T., Freeouf, J.A., Keys, J.E., Jr., Nowacki, G.J., Carpenter, C.A., and McNab, W.H., 2005, Ecological subregions; Sections and subsections for the conterminous United States: Washington, D.C., U.S. Department of Agriculture, Forest Service, scale 1:3,500,000.

Comer, Patrick, Faber-Langendoen, Don, Evans, Rob, Gawler, Sue, Josse, Carmen, Kittel, Gwen, Menard, Shannon, Pyne, Milo, Reid, Marion, Schulz, Keith, Snow, Kristin, and Teague, Judy, 2003, Ecological systems of the United States, A working classification of U.S. terrestrial systems: Arlington, Va., NatureServe, 75 p. (Also available online at http://www.natureserve.org/publications/ usEcologicalsystems.jsp.)

Commission for Environmental Cooperation, 1997, Ecological regions of North America - Toward a common perspective: Montreal, Canada, Commission for Environmental Cooperation, 71 p. (Also available online at http://www.cec.org/ pubs_info_resources/publications/pdfs/english/eco-eng.pdf.)

Dikau, Richard, Brabb, E.E., and Mark, R.M., 1991, Landform classification of New Mexico by computer: U.S. Geological Survey Open-File Report 91-634, 15 p., 2 maps.

Federal Geographic Data Committee, 1997, Vegetation Classification Standard: Federal Geographic Data Committee Document FGDC-STD-005[-1997], 58 p. (Also available online at http://fia.fs.fed.us/documents/pdfs/ Mandate\%202c-FGDC97-STD-005.pdf.) (Superseded by version 2 of the standard; see Federal Geographic Data Committee, 2008.)

Federal Geographic Data Committee, 2008, National Vegetation Classification Standard, Version 2: Federal Geographic Data Committee Document FGDC-STD005-2008 (Version 2), 119 p. (Also available online at http://www.fgdc.gov/standards/projects/FGDC-standardsprojects/vegetation/NVCS_V2_FINAL_2008-02.pdf.)

Franken, S.K., Tyler, D.J., and Verdin, K.L., 2001, Development of a national seamless database of topography and hydrologic derivatives: ESRI International User Conference, 21st, July 9-13, 2001, San Diego, Proceedings, on CD-ROM. (Also available online at http://proceedings.esri.com/library/userconf/proc01/ professional/papers/pap730/p730.htm.)

Gesch, D.B., 2007, The national elevation dataset, chap. 4 of Maune, D.F., ed., Digital elevation model technologies and applications; The DEM users manual, 2nd edition: Bethesda, Md., American Society for Photogrammetry and Remote Sensing, p. 99-118.
Grossman, D.H., Faber-Langendoen, D., Weakley, A.S., Anderson, M., Bourgeron, P., Crawford, R., Goodin, K., Landaal, S., Metzler, K., Patterson, K.D., Pyne, M., Reid, M., and Sneddon, L., 1998, The National Vegetation Classification System; Development, status, and applications, v. 1 of International classification of ecological communities; Terrestrial vegetation of the United States: Arlington, Va., The Nature Conservancy, 126 p. (Also available online at http://www.natureserve.org/library/vol1.pdf.)

Group on Earth Observations, 2005, The Global Earth Observation System of Systems (GEOSS) 10-year implementation plan: Geneva, Group on Earth Observations, 11 p. (Also available online at http://www.earthobservations.org/ docs/10-Year\%20Implementation\%20Plan.pdf.)

Groves, Craig, 2003, Drafting a conservation blueprint; A practitioner's guide to planning for biodiversity: Washington, D.C., Island Press, 404 p.

Groves, Craig, Valutis, Laura, Vosick, Diane, Neely, Betsy, Wheaton, Kimberly, Touval, Jerry, and Runnels, Bruce, 2000, Appendices, v. II of Designing a geography of hope; A practitioner's handbook to ecoregional conservation planning ( $2 \mathrm{~d}$ ed.): Arlington, Va., The Nature Conservancy, variously paged [116 p.]. (Also available online at http://conserveonline.org/library/GOH2-v2.pdf.)

Hammond, E.H., 1964, Classes of land-surface form in the forty-eight States, U.S.A.: Annals of the Association of American Geographers, v. 54, no. 1, map supplement no. 4, scale 1:5,000,000.

Huggett, R.J., 1995, Geoecology; An evolutionary approach: London, Routledge, 320 p.

Interagency Ecosystem Management Task Force, 1995, Overview, v. 1 of The ecosystem approach; Healthy ecosystems and sustainable economies: [Washington, D.C.,] 55 p.

Kruckeberg, A.R., 2002, Geology and plant life; The effects of landforms and rock types on plants: Seattle, University of Washington Press, 362 p.

Li, Bai-Lian, 2000, Why is the holistic approach becoming so important in landscape ecology?: Landscape and Urban Planning, v. 50, no. 1-3, p. 27-41, doi:10.1016/S01692046(00)00078-5.

Loveland, T.R., Sohl, T.L., Stehman, S.V., Gallant, A.L., Sayler, K.L., and Napton, D.E., 2002, A strategy for estimating the rates of recent United States land-cover changes: Photogrammetric Engineering \& Remote Sensing, v. 68, no. 10, p. 1091-1099.

Lowry, J.H., Jr., Ramsey, R.D., Boykin, Ken, Bradford, David, Comer, Patrick, Falzarano, Sarah, Kepner, William, Kirby, Jessica, Langs, Lisa, Prior-Magee, Julie, Manis, Gerald, O'Brien, Lee, Pohs, Keith, Rieth, Wendy, Sajwaj, Todd, 
Schrader, Scott, Thomas, K.A., Schrupp, Donald, Schulz, Keith, Thompson, Bruce, Wallace, Cynthia, Velasquez, Christian, Waller, Eric, and Wolk, Brett, 2005, The Southwest Regional Gap Analysis Project; Final report on land cover mapping methods: Logan, Utah, Utah State University, Remote Sensing/GIS Laboratory, 50 p., available online at http://earth.gis.usu.edu/swgap/swregap_landcover_report.pdf. (Accessed March 16, 2009.)

McMahon, Gerard, Gregonis, S.M., Waltman, S.W., Omernik, J.M., Thorson, T.D., Freeouf, J.A., Rorick, A.H., and Keys, J.E., 2001, Developing a spatial framework of common ecological regions for the conterminous United States: Environmental Management, v. 28, no. 3, p. 293-316, doi:10.1007/ s0026702429.

Millennium Ecosystem Assessment, 2005, Ecosystems and human well-being; Our human planet; Summary for decision makers: Washington, D.C., Island Press, 128 p.

Muchoney, D.M., 2008, Earth observations for terrestrial biodiversity and ecosystems: Remote Sensing of Environment, v. 112, no. 5, p. 1909-1911, doi:10.1016/j.rse.2008.01.003.

Myers, M.D., Ayers, M.A., Baron, J.S., Beauchemin, P.R., Gallagher, K.T., Goldhaber, M.B., Hutchinson, D.R., LaBaugh, J.W., Sayre, R.G., Schwarzbach, S.E., Schwieg, E.S., Thormodsgard, J., van Riper, C., III, and Wilde, W., 2007, USGS goals for the coming decade: Science, v. 318, no. 5848, p. 200-201, doi:10.1126/science.1147228.

NatureServe, 2008, NatureServe Explorer-Ecological communities \& systems [database]: NatureServe database, version 1.08, at http://www.natureserve.org/explorer/servlet/ NatureServe?init=Ecol. (Accessed in March 2008.)

Odum, E.P., 1953, Fundamentals of ecology: Philadelphia, W.B. Saunders, 384 p.

Olson, D.M., Dinerstein, Eric, Wikramanayake, E.D., Burgess, N.D., Powell, G.V.N., Underwood, E.C., D'amico, J.A., Itoua, Illanga, Strand, H.E., Morrison, J.C., Loucks, C.J., Allnutt, T.F., Ricketts, T.H., Kura, Yumiko, Lamoreux, J.F., Wettengel, W.W., Hedao, Prashant, and Kassem, K.R., 2001, Terrestrial ecoregions of the world; A new map of life on Earth: BioScience, v. 51, no. 11, p. 933-938.

Omernik, J.M., 1987, Ecoregions of the conterminous United States: Annals of the Association of American Geographers, v. 77 , no. 1 , p. $118-125$.

Redford, K.H., Coppolillo, Peter, Sanderson, E.W., Da Fonseca, G.A.B., Dinerstein, Eric, Groves, Craig, Mace, Georgina, Maginnis, Stewart, Mittermeier, R.A., Noss, Reed, Olson, David, Robinson, J.G., Vedder, Amy, and Wright, Michael, 2003, Mapping the conservation landscape: Conservation Biology, v. 17, no. 1, p. 116-131, doi:10.1046/ j.1523-1739.2003.01467.x.
Ricketts, Taylor, Dinerstein, Eric, Olson, David, Loucks, Colby, Eichbaum, William, DellaSalla, Dominick, Kavanagh, Kevin, Hedao, Prashant, Hurley, Patrick, Carney, Karen, Abell, Robin, and Walters, Steven, 1999, Terrestrial ecoregions of North America; A conservation assessment: Washington, D.C., Island Press, 508 p.

Rivas-Martinez, Salvador, and Rivas y Sáenz, Salvador, 2009, Synoptical Worldwide Bioclimatic Classification System (summarized table): Centro de Investigaciones Fitosociológicas [Phytosociological Research Center] Web site at http://www.globalbioclimatics.org/book/namerica2/ table.htm.

Ryan, K.C., Lee, K.M., Rollins, M.G., Zhu, Z.-L., Smith, Jim, and Johnson, Darren, 2006, LANDFIRE; National vegetation and fuel mapping for fire management planning [abs.]: Forest Ecology and Management, v. 234, supplement 1, p. S220, doi:10.1016/j.foreco.2006.08.247.

Salt, G.W., 1979, A comment on the use of the term emergent properties: The American Naturalist, v. 113, no. 1, p. 145-148.

Sayre, Roger, Bow, Jacquie, Josse, Carmen, Sotomayor, Leonardo, and Touval, Jerry, 2008, Terrestrial ecosystems of South America, chap. 9 of Campbell, J.C., Jones, K.B., Smith, J.H., and Koeppe, M.T., eds., North America Land Cover Summit: Washington, D.C., Association of American Geographers, p. 131-152. (Also available online at http://www.aag.org/books/nalcs/.)

Sayre, Roger, Yanosky, Alberto, and Muchoney, Douglas, 2007, Mapping global ecosystems; The GEOSS [Global Earth Observation System of Systems] approach, in Group on Earth Observations Secretariat, ed., The full picture: Leicester, U.K., Tudor Rose, p. 231-232. (Also available online at http://www.earthobservations.org/docs_pub.shtml.)

Scott, J.M., Davis, F.W., McGhie, R.G., Wright, R.G., Groves, Craig, and Estes, John, 2001, Nature reserves; Do they capture the full range of America's biological diversity?: Ecological Applications, v. 11, no. 4, p. 999-1007.

Secretariat of the Convention on Biological Diversity, 2000, Sustaining life on Earth; How the Convention on Biological Diversity promotes nature and human well-being: Montreal, Secretariat of the Convention on Biological Diversity, 20 p., ISBN 92-807-1904-1. (Accessed March 12, 2009, at http://www.cbd.int/convention/guide.shtml.)

Soller, D.R., and Reheis, M.C., comps., 2004, Surficial materials in the conterminous United States: U.S. Geological Survey Open-File Report 03-275, scale 1:5,000,000, available only online at http://pubs.usgs.gov/of/2003/of03-275/.

Takhtajan, A.L., 1986, Floristic regions of the world (English translation by T.J. Crovello and Arthur Cronquist): Berkeley, University of California Press, 522 p. 
Tansley, A.G., 1935, The use and abuse of vegetational concepts and terms: Ecology, v. 16, no. 3, p. 284-307.

Thornton, P.E., Running, S.W., and White, M.A., 1997, Generating surfaces of daily meteorological variables over large regions of complex terrain: Journal of Hydrology, v. 190, no. 3-4, p. 214-251.

True, C.D., and MoRAP Staff, 2002, Landforms of the lower Mid-West: Missouri Resource Assessment Partnership MoRAP Map Series MS-2003-001, scale 1:1,500,000. (Also available online at http://www.cerc.usgs.gov/morap/ Maps.aspx.)

True, C.D., Gordon, Taisia, and Diamond, David, 2000, How the size of a sliding window impacts the generation of landforms: Missouri Resource Assessment Partnership (MoRAP) PowerPoint presentation, 43 slides, available online at http://www.cerc.usgs.gov/morap/Projects. aspx?ProjectId=17. (Accessed March 17, 2009).

U.S. Bureau of Land Management, 1994, Ecosystem management in the BLM-From concept to commitment: U.S. Bureau of Land Management [Publication] BLM/SC/ Gi-94/005+1736, 16 p.

U.S. Department of Agriculture Forest Service, 2006a, Land management planning (as amended January 31, 2006, in amendment 1900-2006-2), chap. 1920 of FSM (Forest Service Manual) 1900_Planning: Washington, D.C., U.S. Department of Agriculture Forest Service, 69 p. (Also avail- able online as "FSM 1920 Land Management Planning" at http:/www.fs.fed.us/emc/nfma/index5.html.)

U.S. Department of Agriculture Forest Service, 2006b, Science and sustainability (as amended January 31, 2006, in amendment 1909.12-2006-5), chap. 40 of FSH (Forest Service Handbook) 1909.12-Land management planning handbook: Washington, D.C., U.S. Department of Agriculture Forest Service, 34 p. (Also available online as "FSH 1909.12, Chapter 40, Science and Sustainability" at http://www.fs.fed.us/emc/nfma/index5.html.)

U.S. Fish \& Wildlife Service, 2009, National Wetlands Inventory: U.S. Fish \& Wildlife Service data layers available at http://www.fws.gov/wetlands/Data/index.html.

Verdin, K.L., 2000, Development of the National Elevation Dataset-Hydrologic Derivatives (NED-H): ESRI International User Conference, 20th, June 26-30, 2000, San Diego, Proceedings, available online at http://proceedings.esri.com/library/userconf/proc00/ professional/papers/PAP397/p397.htm.

Weiss, A.D., 2001, Topographic position and landforms analysis: Annual ESRI User Conference, 21st, San Diego, Calif., 2001, poster presentation.

Wu, Jianguo, and Hobbs, R.J., 2007, Landscape ecology; The state-of-the-science, chap. 15 of $\mathrm{Wu}$, Jianguo, and Hobbs, R.J., eds., Key topics in landscape ecology: Cambridge, U.K., Cambridge University Press, p. 217-284. 


\section{$\frac{\mathbb{2}}{3}$}

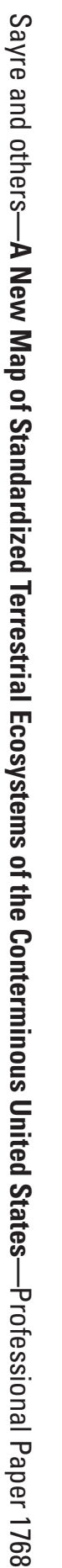

8 Printed on recycled paper

ISBN $978-1-4133-2432-9$ 